\title{
Factors influencing medical specialists' dual practice in the Islamic Republic of Iran
}

Mahboubeh Bayat, ${ }^{1,2}$ Azad Shokri, ${ }^{3}$ Mahmoud Khodadost, ${ }^{4,5}$ Hamed Fattahi, ${ }^{6}$ Elmira Mirbahaeddin, ${ }^{7}$ Iraj Harirchi, ${ }^{8}$ Ali Akbari-Sari, ${ }^{9}$ Gholamhossein Salehi Zalani ${ }^{2}$ and Roghayeh Khalilnezhad ${ }^{10}$

${ }^{1}$ Gerash University of Medical Sciences, Gerash, Islamic Republic of Iran. ${ }^{2}$ Center for Health Human Resources Research \& Studies, Ministry of Health and Medical Education, Tehran, Islamic Republic of Iran. ${ }^{3}$ Social Determinants of Health Research Center, Kurdistan University of Medical Sciences,

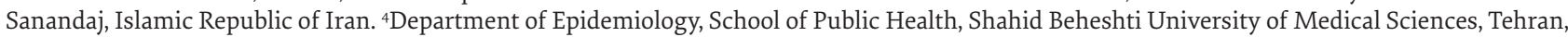
Islamic Republic of Iran. ${ }^{5}$ Department of Epidemiology, School of Public Health, Iran University of Medical Sciences, Tehran, Islamic Republic of Iran. ${ }^{6}$ Department of Health Services Management, School of Health Management and Information Sciences, Iran University of Medical Sciences, Tehran, Islamic Republic of Iran. ${ }^{7}$ Telfer School of Management, University of Ottawa, Ontario, Canada. ${ }^{8}$ Department of Surgery, School of Medicine, Tehran University of Medical Sciences, Tehran, Islamic Republic of Iran. ${ }^{~}$ Department of Health Management and Economics, School of Public Health, Tehran University of Medical Sciences, Tehran, Islamic Repubic of Iran. ${ }^{10}$ Health Management and Economics Research Center, Iran University of Medical Sciences, Tehran, Isamic Republic of Iran. (Correspondence to: Roghayeh Khalilnezhad: r.khalilnezhad@gmail.com).

\begin{abstract}
Background: Dual practice (DP) is performing several different jobs at the same time and has effects on healthcare services delivery.

Aims: To identify the causes of medical specialists' tendency towards DP in the Islamic Republic of Iran.

Methods: We used a qualitative approach to identify the factors affecting DP in medical specialists in 2016 . We used a purposive and outlier sampling method to conduct semistructured deep interviews with 14 key informants. The data analysis was performed simultaneously with data collection using thematic content analysis by MAXQDA (version 10.0). Interviews continued up to data saturation. The quality of the study was ensured by addressing the criteria of Guba and Lincoln.

Results: The results of the interviews showed six themes and 16 subthemes for specialists' propensity to DP. Major themes included financial incentives, cultural attitudes about professional identity of physicians, experience and academic level of specialists, controlling approaches in the public sector, available infrastructure for responding to the population needs in the public sector, and regional characteristics of health service locations.

Conclusions: Medical specialists' DP is a multidimensional issue, influenced by different factors such as financial incentives, cultural attitudes and available infrastructure. Considering the capacities and conditions of each country, control and management of this phenomenon require regulatory and incentive mechanisms, which in the long term can modify private and public sector differences and increase the willingness of doctors to work in the public sector.
\end{abstract}

Keywords: dual practice, medical specialist, private practice, public sector, Islamic Republic of Iran

Citation: Bayat M; Shokri A; Khodadost M; Fattahi H; Mirbahaeddin E; Harirchi I; et al. Factors influencing medical specialists' dual practice in the Islamic Republic of Iran. East Mediterr Health J. 2018;24(9):877-887. https://doi.org/10.26719/2018.24.9.877

Received: 02/10/17; accepted: 24/05/18

Copyright (C) World Health Organization (WHO) 2018. Some rights reserved. This work is available under the CC BY-NC-SA 3.o IGO license (https:// creativecommons.org/licenses/by-nc-sa/3.o/igo).

\section{Introduction}

According to the World Health Organization (WHO), the global shortage of physicians, midwives and nurses was estimated to be 11.6 million in 2013 (1). Dual practice (DP) is defined as performing several different jobs at the same time, and it has emerged as a reason for the workforce shortage, especially in low- and middle-income countries $(2,3)$. This phenomenon occurs in most countries, even where it is banned. For example, nearly all highly skilled medical professionals in Austria, $90 \%$ of general physicians in Ireland, and $60 \%$ of general physicians in the United Kingdom of Great Britain and Northern Ireland work in private and public hospitals (4). Physicians work in both public and private hospitals and clinics to raise their income in most countries (5). Other factors that attract physicians to DP include greater flexibility of private practice, more opportunities for patient contact and more self-management $(6,7)$.

Concerns about the effects of DP on different aspects such as accessibility to healthcare services have made it a significant issue in the health systems in many countries (8). The mechanisms used for management and control of DP, as well as economic, social, cultural and legal conditions in different countries, result in DP having different consequences on health systems $(9,10)$. These consequences include: reduced working hours of doctors; absenteeism; limited access to dual practitioners due to the lack of full-time attendance (especially in the public sector) $(4,11)$; shift of patients from the public to private sector due to better quality of services in the latter; conflicts of interest of physicians who simultaneously work in private and public sectors (12-14); greater 
pressure on nurses and other health workers who are working with dual practitioners (12); and the request for clandestine or informal payments in areas with no (or limited) private facilities, in which DP is not feasible (15).

Different countries have different approaches ranging from total freedom to total prohibition on dealing with DP. Indonesia and Egypt have adopted full-freedom strategies due to workforce surpluses and inability of the public sector to pay more salaries (16). Norway (17) and Bangladesh (18) have encouraged physicians to withdraw from the private sector through increasing public revenues. Some countries such as India, Italy, Portugal and Spain are providing incentives for public services to retain specialists (14). Other countries such as some provinces of Canada (19), China, Kenya, Zambia (20), Greece (21) and some Indian states (22) have supported a full ban on DP, with interventions such as creating a desirable work environment, financial monitoring, and providing financial resources for the public sector, through taxation.

In the Islamic Republic of Iran, DP of public physicians in the private sector is one of the main challenges to the health system. According to one study, the rate of DP of public medical specialists in the private sector is $42.3 \%$ (23). Although there is a complete ban on DP for fulltime specialists according to national legislation and regulation (24), factors such as the need to increase the share of health expenditure from public sources and determining tariffs based on actual costs, have caused low enforcement of these laws and regulations (25). In the Islamic Republic of Iran two reviews of the reasons for DP among physicians point to factors such as a tendency towards simultaneous use of public and private sector benefits, monetization, institutional characteristics of the public sector including control approaches and work pressures, and individual characteristics of physicians $(26,27)$.

Because of the limited number of studies and lack of evidence on the contributing factors to specialists' DP in the Islamic Republic of Iran and low- and middle-income countries (28), the present study aimed to identify the causes of the tendency for medical specialists towards DP in the Islamic Republic of Iran through interview-based qualitative research of the views of medical university directors and managers.

\section{Methods}

We used a qualitative approach via content analysis to identify the factors affecting DP among all medical specialists. The data were collected through in-depth, face-to-face interviews about the reasons for specialists' tendency towards DP. This study was part of a comprehensive study conducted in 2017, in which, after calculating the prevalence of DP by specialty and province, the provinces were divided into 3 groups with high, middle and low rates of DP (23).

We used a purposive and outlier sampling method (29) to select key participants from three groups of universities with high, middle and low rates of DP (23) to cover all the Iranian provinces. Key informants of universities were determined in a focused discussion group with some administrative and academic experts familiar with the university sector. The focused discussion group selected the deputies for curative affairs of medical universities as key informants for interview. A letter were sent inviting them to participate and interviews continued until the saturation stage based on the researchers' ongoing and cumulative judgement, using a hybrid saturation model (inductive thematic saturation and data saturation) $(30,31)$.

The semistructured interviews were conducted by two experienced researchers among the authors, AS and MB. Each interview lasted an average of 35 minuntes (range 25-45 minutes). All interviews were audiotaped after obtaining permission from the participants and transcribed on the same day.

For quality assurance of the research as well as validating the data, the proposed criteria of Guba and Lincoln were used (31). To ensure credibility of the interview data, we used peer debriefing as well as member checking. The transcripts of the interviews were given to the participants to read in order to make sure that they were transcribed correctly. Moreover, each transcript was carefully and independently reviewed and labelled by two persons, including one of the researchers and another who held impartial views of the study (32). For dependability and conformability of the data, we used different methods such as in-depth methodological descriptions, maintaining all documentation related to the study, and trying to obtain comments from others. Transmissibility of data and the ability to follow the study path by others was guaranteed by actions such as providing a complete description of the themes, presenting participant features, description of data collection method, and making examples of contributors.

For content analysis we used a 3-step model (33) including: identifying the early themes and subthemes of the key points of the interviews; identifying concepts, themes and subthemes based on comparisons, understanding overlaps and boundaries; and extraction of themes for creating the main concepts by listing subthemes that were applied systematically to the whole data set. Afterwards, through two discussion sessions with the experts, the extracted themes and subthemes were discussed to categorize the final themes. The content analysis of the data started from the first interview at the same time as conducting the other interviews. The data were analysed using MAXQDA version 10.0.

We provided a documented interview guide to: explain clearly the purpose of the study to the interviewees before the interviews; ensure the confidentiality of the information of the participants at all stages of the study by using the codes instead of names; ensure that participants had freedom to leave the study at any time; and observe the ethical principles of recording and storing information collected at all stages of the research. 


\begin{tabular}{|c|c|c|c|c|c|c|c|}
\hline Participant code & Interview length (min) & Sex & Position & University & Major & DP level & No. of subthemes \\
\hline $\mathrm{P} 1$ & 38 & Male & $\mathrm{DCA}$ & North Khorasan & MS & $36 \%$ & 44 \\
\hline $\mathrm{P}_{2}$ & 42 & Male & DCA & Hormozgan & $\begin{array}{l}\text { Health } \\
\text { policy }\end{array}$ & $21 \%$ & 35 \\
\hline $\mathrm{P}_{3}$ & 32 & Male & HAM & Ilam & GP & $18.9 \%$ & 24 \\
\hline $\mathrm{P}_{4}$ & 35 & Male & HAM & Gilan & GP & $69 \%$ & 25 \\
\hline $\mathrm{P}_{5}$ & 30 & Female & DCA & Tehran & MS & $57 \%$ & 20 \\
\hline P6 & 45 & Male & Deputies of ministry & - & MS & - & 33 \\
\hline $\mathrm{P}_{7}$ & 36 & Female & $\begin{array}{l}\text { Deputies for research } \\
\text { affairs }\end{array}$ & Zabol & GP & $26 \%$ & 29 \\
\hline P8 & 30 & Male & DCA & Birjand & MS & $27 \%$ & 37 \\
\hline P9 & 25 & Male & DCA & Mazandaran & MS & $46 \%$ & 23 \\
\hline P10 & 30 & Male & DCA & Kurdestan & MS & $30 \%$ & 18 \\
\hline P11 & 35 & Male & HAM & Isfahan & GP & $47 \%$ & 32 \\
\hline $\mathrm{P} 12$ & 33 & Male & DCA & Tabriz & MS & $57 \%$ & 40 \\
\hline $\mathrm{P} 13$ & 36 & Male & DCA & Semnan & MS & $24 \%$ & 30 \\
\hline $\mathrm{P} 14$ & 41 & Male & $\mathrm{DCA}$ & Shiraz & MS & $24 \%$ & 43 \\
\hline
\end{tabular}

$D C A=$ deputy for curative affairs; $G P=$ general practitioner; $H A M=$ hospital affairs manager; $M S$ = medical specialist.

\section{Results}

We interviewed 14 participants with an average age of 51 (standard deviation 3.6) years. The majority of them were male $(85 \%)$, deputies for curative affairs of medical universities $(71 \%)$ and medical specialists $(65 \%)$ (Table 1$)$. Six themes, 16 subthemes and 41 issues were identified and confirmed by participants (Table 2). The level of medical specialists' DP in column 7 of Table 1 is based on the results of the first phase of the main study (23). The codes extracted from the interviews were presented as 6 themes: financial incentives; cultural attitudes about professional identity of physicians; experience and academic level of specialists; controlling approaches in the public sector; available infrastructure for responding to the population needs in the public sector; and regional characteristics of health service locations. These themes included the subthemes and issues that are explained below.

\section{Financial incentives}

Financial incentives were organized into 2 subthemes, income gap between public and private sectors, and owning of private hospital shares by public specialists.

\section{Income gap between public and private sectors}

Income gap between public and private sectors was one of the main factors affecting the behaviour and decisions of Iranian specialists towards DP. One of the main issues for income gap was the irrational difference between private and public sector tariffs. According to the Iranian Universal Insurance Law (34), tariffs are calculated based on cost price. Consideration of capital gains and depreciation means that private sector tariffs were more expensive than those of the public sector. Participant $10 \mathrm{com}$ mented: "In the private sector, for the same therapeutic treatment, physicians are paid about eight times higher than in the public sector".
Service tariffs were defined on the basis of two factors: hotel services and the professional component of the service (representing the effort, skill and risk of service provision). What was paid to physicians was the percentage of the assigned tariff for each service based on the performance of the physicians. This percentage varied between public and private sectors, and created income differences between the sectors. As Participant 10 stated: "In the public sector, on average, the doctor is paid $40 \%$ of a professional component of a services tariff compared with $80 \%$ in the private sector".

There was a difference in tax rates between private and public sectors in all industries and sectors and it was not specific to the health sector and doctors. Due to the close relationship between private and public health centres, the difference in taxation was one of the factors that accounted for the specialists' tendency to want to work in the private sector. Participant 4 said: "Currently, the public sector income tax is $20 \%$ but in the private sector it is $3 \%$ to $5 \%$, for the same job".

The imposition of the income ceiling only in public hospitals has exacerbated this income gap. According to some experts, in the public sector, for payments $<100$ million Iranian rials, $80 \%$ is paid to the doctors, but for higher payments, the percentage share of the doctor is reduced gradually (participants 1 and 8).

Another problem that all the experts agreed upon was delays in paying physicians in the public sector due to inappropriate performance of insurance organizations. As Participant 4 pointed out: "They prefer to get $180-200$ million rials this year instead of earning 400 million rials next year".

\section{Owning of private hospital shares by public specialists}

One of the factors influencing DP among public sector physicians was being a private hospital shareholder. 


\section{Table 2 Main factors affecting specialists' tendency towards DP}

Theme
$\begin{aligned} & \text { Financial incentives } \\ & \text { Income gap between public and } \\ & \text { private sectors }\end{aligned}$

$\begin{aligned} & \text { Owning of private hospital shares } \\ & \text { by public specialists }\end{aligned}$

\section{Cultural attitudes about} professional identity of physicians

Attitude of the community towards physicians' identity

Attitude of physicians towards their occupation

Academic level of specialists

\section{Controlling approaches in the} public sector

\begin{tabular}{ll}
$\begin{array}{l}\text { Experience and academic level of } \\
\text { specialists }\end{array}$ & $\begin{array}{l}\text { Experience and reputation of } \\
\text { specialists }\end{array}$ \\
& Academic level of specialists \\
\hline $\begin{array}{l}\text { Controlling approaches in the } \\
\text { public sector }\end{array}$ & $\begin{array}{l}\text { Laws and plans supporting being } \\
\text { full-time in the public sector }\end{array}$
\end{tabular}

Bureaucratic monitoring mechanisms in public sector versus relative freedom of private sector

Available infrastructure for
responding to population needs in
public sector

Imbalance between facilities in public hospitals with needs of the regions

Incomplete chain of specialized medical services in some public hospitals

\section{Issue}

Type of impact

Irrational disparity of tariffs

Specialists' share of hospitals' income

Positive

Positive

High tax rate on public sector

Positive

specialists' incomes

Income ceiling in public hospitals

Positive

Delay in payments in public hospitals

Positive

Being a beneficiary of public

Positive

medical specialists as private sector shareholders

Use of specialists from their public credibility

Importance of the office in recognizing physicians

Importance of the office in quality of services provided

Relationship between physicians professional identity and having an office

Fear of getting away the patients in the absence of the office

Obliging newly graduates to work in under served areas

Inability of young specialists to compete with well-known specialists

Owning a medical office license by more experienced specialists

Unwillingness of more-experienced specialists to join HTP

Upgrading academic specialists

Positive

Positive

Positive

Positive

Positive

Reducing the gap between public and private tariffs due to HTP

Compulsory full-time membership in HTP for new graduates

Prohibition of full-time specialists for DP

Cooperation of insurance organizations for identifying

specialists engaging DP

Low control of specialists to receive informal fees

High occupational bureaucracies

Existence of the punitive mechanism such as to complete patient records

Lack of commitment of public hospital heads to prohibition of DP

Inadequate equipment for specialists

To provide equipment without regard to stratification of health services in the private sector

Lack of adequate hospital

infrastructure

Incomplete team of specialists

Negative

Positive

Positive

Negative

Positive

Negative

Negative

Negative

Negative

Positive

Positive

Positive

Positive

Positive

Positive

Positive

Positive

Positive

Attracting well-known specialists in the private sector

Impossibility of providing a full range

Positive

of specialized medical services

Lack of sustainability of medical teams 
Table 2 Main factors affecting specialists' tendency towards DP (concluded)

\begin{tabular}{|c|c|c|c|}
\hline Theme & Subtheme & Issue & Type of impact \\
\hline \multirow[t]{9}{*}{$\begin{array}{l}\text { Regional characteristics of health } \\
\text { service locations }\end{array}$} & Number of private sector facilities & $\begin{array}{l}\text { High capacity of the private sector in } \\
\text { metropolitan areas }\end{array}$ & Positive \\
\hline & $\begin{array}{l}\text { Privileges and attractions of } \\
\text { private sector }\end{array}$ & $\begin{array}{l}\text { Higher number of elective cases in the } \\
\text { private hospitals }\end{array}$ & Positive \\
\hline & \multirow[t]{2}{*}{ Frequency and diversity of visits } & $\begin{array}{l}\text { To monopolize patients of } \\
\text { underserved regions by well-known } \\
\text { specialists } \\
\text { Low frequency of related medical } \\
\text { cases for subspecialists }\end{array}$ & Negative \\
\hline & & Low patient volume in hospitals & Positive \\
\hline & \multirow{3}{*}{$\begin{array}{l}\text { Conditions and characteristics of } \\
\text { hospitals }\end{array}$} & Types of hospitals & Positive/ negative \\
\hline & & Reputation of the hospital & Positive/ negative \\
\hline & & Hospital income rate & Positive/ negative \\
\hline & $\begin{array}{l}\text { Different geographical extent of } \\
\text { regions }\end{array}$ & $\begin{array}{l}\text { Small size of cities in underserved } \\
\text { regions }\end{array}$ & Negative \\
\hline & $\begin{array}{l}\text { Economic status of communities } \\
\text { in different regions }\end{array}$ & $\begin{array}{l}\text { Different rates of referral to public } \\
\text { and private sectors }\end{array}$ & Positive/ negative \\
\hline
\end{tabular}

$\mathrm{DP}=$ dual practice HTP = health transformation plan .

Some experts believed that the main shareholders of the private hospitals were public sector doctors, which led to an increased tendency towards DP in the private sector. Others believed that experts, in particular, faculty members, use their credibility in the public sector to seek patients in the private sector (Participant 1).

\section{Cultural attitudes about professional identity of physicians}

Cultural factors can have a significant effect on human behaviour in the long term. In this study, the behaviour of physicians was partly shaped by community culture through the two following themes.

\section{Attitude of the community towards doctors' identity}

The experts in this study considered that societal attitudes were an important factor in changing specialists' behaviour and encouraging them to work in the private sector. According to Participant 4:

The community looks at a doctor who does not have an office, like a student. Patients in the hospital ask us where your office is. Many people may go to the public sector for visiting, but they go to the private sector for surgery. Because they think the public physicians are students or interns and have not enough experience. Also, patients are looking for their doctor's office address for future reference because they think that the services provided in an office have higher quality.

\section{Attitude of physicians towards their occupation}

Some doctors felt that their identity was related to having an office. One of them who worked full time in the Ministry of Health said: "Nobody thinks I am a doctor. I have not been wearing white overalls for a long time. People think of a doctor with a white coat" (Participant 4). Experts also stated that some of the doctors who worked at university headquarters tended to move away from the medical profession to the office and private sector for fear of being isolated professionally.

\section{Experience and academic level of specialists}

This theme was organized into two subthemes, experience and reputation of specialists and their academic level.

\section{Experience and reputation of specialists}

Duration of employment, permanent or temporary employment, and academic degree of specialists directly affected their attitude and capacity for DP. Some experts indicated that, since the majority of young specialists were employed as Zarib K (recruitment contract in which medical specialty graduates who are legally committed to certain obligations fulfil these obligations in a health-related centre), they had a lower level of DP. This was because Zarib-K specialists in the Islamic Republic of Iran have mandatory commitments to work in deprived areas after completing their education, based on current laws (24). In addition, Participant 12 commented: "Young doctors have more energy and can do more working hours. We have given them a residency fee and the other benefits of full-time working. In exchange, they were not permitted to engage in DP". Also, entering the health market is more risky for young doctors because they are less well known and they dare not compete with doctors with an established record in the private sector. So, they stay for several years in the public sector to gain experience (Participant 10).

Experts said that all physicians with DP, especially in underserved areas, were experienced specialists who were not subject to enforcement of the DP prohibition law. These physicians have already fulfilled their obligations and they have an office licence (Participant 8). Participant 13. referring to the Health Transformation Plan (HTP), 
which encourages young doctors to become full-time through a number of benefits in exchange for a ban on having an office, believed that since more experienced doctors have a private office, they are less involved in the HTP and they do not need to comply with its rules.

\section{Academic level of specialists}

The academic level of specialists was discussed by some participants. As Participant 3 indicated: "Since doctors do not have DP restrictions after acquiring an associate professor's degree, they have more multiple jobs in the private sector".

\section{Controlling approaches in the public sector}

There were two subthemes in this theme; one of which decreased DP and the other had an increasing effect. The control approaches of the Iranian government were a factor in the prevalence of DP among specialists.

\section{Laws and plans that support working full time in the public sector}

HTP rules have had the effect of decreasing DP, according to the experts' opinions. HTP has controlled the level of DP in the Islamic Republic of Iran through reducing the gap between public and private tariffs, providing compulsory full-time rules for specialists entered in the plan, and abolition of the benefits of being full-time as soon as the authorities become aware of involvement in DP. Universities are aware of physicians' DP through various sources. For example, in coordination and agreement between insurance and universities, the insurance organizations declare the names of full-time public medical specialists, whose stamp and names are registered in the insurance records of private facilities, and which indicates they are also active in private clinics.

\section{Bureaucratic monitoring in public sector versus relative freedom of private sector}

Some experts believed that the use of a punitive system as well as the existence of rigid regulations in some university hospitals have increased the migration of doctors to the private sector. It was reported that if doctors do not complete their patients' records or they are delayed at their workplace, regardless of how efficient and effective they are, their payments are deducted (Participant 2).

Some experts argued that private hospitals were more likely to support doctors and sometimes hide doctors' errors in order to maintain their reputation and compete with other private hospitals. The lack of supervision of private hospitals by the Ministry of Health means that there are fewer direct controls on doctors in the private sector compared with the public sector. For example, there are fewer restrictions for receiving informal payments (Participant 2). According to some experts, despite the regulatory mechanisms in the public sector, some managers had no commitment to comply with laws related to full-time work in the public sector. Participant 7 acknowledged that managers and officials who themeselves are currently engaged in DP do not control other doctors involved in DP.

\section{Available infrastructure for responding to the population needs in the public sector}

The low level of public sector accountability to the changing needs of the community, mismatching the allocation of resources to the needs of different regions, the lack of proper development in line with the changing needs of the population, and inconsistency in the levels of resource utilization all had a direct effect on the willingness of specialists to engage in DP. This theme included 2 subthemes.

\section{Imbalance of facilities in public hospitals with the needs of the regions}

In the public sector, the lack of necessary equipment and infrastructure, such as shortage of space in clinics and number of treatment and operating rooms, had led to no possibility of providing services, and meant there was no service provision for physicians at some times of the day or some days of the week. Participant 4 stated that a fulltime faculty member in public hospitals may be working just one day and the other working days they may be free because there are not sufficient operating room spaces or inpatient beds to fill their working time. In contrast, the private sector, without complying with health services stratification regulations, which determine what equipment should be present in each health facility, provides all the necessary equipment and expertise for the hospital. Participant 7 commented: "Equipment in public hospitals has not changed for 15 years. Despite the increase in population, as well as the increase in the number of specialists, the numbers of beds, operating rooms and other facilities have remained constant. In contrast, the private sector has grown tremendously during these years".

\section{Incomplete chain of specialized medical services in some public hospitals}

Sometimes the referral of patients to private hospitals occured because of the absence of a complete specialist team. For example, Participant 2 said that some general hospitals do not have a cardiologist to complete treatment, or though a trauma specialist is available, they do not have a neurologist. In addition, public sector teams do not have sufficient stability due to the high turnover of supportive specialists. One of the reasons is that, in public hospitals, most anaesthetists in underserved areas are Zarib K, who work on a compulsory basis for a limited period of time in a hospital, and soon after completing their commitments, they leave the hospital. In turn, the private sector has the complete authority and capacity to attract well-known and specialists on a permanent basis. With regard to the incomplete range of specialized medical services, Participant 4 mentioned that:

In some hospitals, some specialized services are not complete due to lack of doctors. For example, there are only two orthopedic surgeons. As a result, the hospital only has access to orthopaedic services for 10 days a month, and on the other days, the specialists refer their patients to the referal hospitals or to the their private hospitals. 


\section{Regional characteristics of health service locations}

This theme included six subthemes. The differences in cultural characteristics and the diversity of the regions in the country were expressed as factors affecting the tendency towards DP.

\section{Number of private sector facilities}

There was a direct relationship between the number of private sector facilities and DP. The high capacity of the private sector in metropolitan areas increased the probability of working in these centres (Participant 5). Also, "In underserved areas, only provincial centers have private hospitals, and there are only private offices in other cities. Therefore, the possibility of DP in these cities is low and limited to the private office." (Participant 4).

\section{Privileges and attractions of the private sector}

The higher number of elective rather than emergency cases in private compared with public hospitals was an attraction for this sector. Participant 2 stated that private hospitals admit patients with fewer problems, therefore reducing conflict and stress for doctors.

\section{Frequency and diversity of visits}

The high rates and diversity of visits in the metropolitan as opposed to deprived areas increased the rate of DP in these areas. In underserved regions, due to limited population, visits to the outpatient department were not high. Therefore, only the well-known specialists monopolized patients, and for other new doctors, due to the cost of an office and the low population, DP was not effective. Public hospitals in developed regions have more facilities and more patients, and public hospitals in less developed regions have fewer patients. This adversely affects the income of doctors, which increases their desire for DP to obtain more income (Participant 1).

\section{Conditions and characteristics of hospitals}

Conditions and characteristics of hospitals, including their type of activity, were effective factors in DP. Participant 4 stated: "In teaching hospitals, faculty specialists use the capacity of residents to visit their patients and cover their on-call time, and instead spend their working hours in the private sector." Participant 6 stated, "The more specialized the hospital, the more subspecialized physicians are employed, but given the specialty differentiation, the number of referrals for patients decreased, and as a result, the probability of DP increases." Specialists had different behaviour based on the reputation of the hospital. If they worked in more well-known hospitals or hospitals with higher income, their inclination to work in other hospitals was reduced.

\section{Different geographical extent of regions}

The small size of cities in underserved regions means that specialist involvement in DP is easily made known, so doctors are not usually involved in DP (Participant 8).

\section{Economic status of communities in different regions}

There were fewer referrals to the private sector in low-income areas. Participant 2 stated: "The people in these areas are mostly covered by social insurance and unable to pay the difference between the public and private sector. So, they are willing to wait two days in the public sector, to pay a lower fee". The inclination to work in the private sector is higher in high-income regions; therefore, the private sector was more active and responsive to doctors in this areas.

\section{Discussion}

Interviews were an appropriate method to understand participants' experiences and different perspectives. This method can provide meaningful data that are not achievable through quantitative methods (35). In addition, considering that this study was carried out after a quantitative study that ranked DP status throughout the country, our findings confirm the factors related to the specialists' tendency towards DP in three groups with high, middle and low rates of DP, and can inform policy-making in developing countries. We identified six main factors that influence the specialists' tendency towards DP.

One of the main factors that encourages specialists to be involved with DP is the difference in payments between the private and public sectors, which is aggravated by the lower tariffs as well as the payment ceiling in the public sector. Similarly, in other studies, income was one of the main factors affecting physicians' behaviour and their decision to undertake DP in countries of all income levels (36). In China, despite the complete banning of DP, $29.6 \%$ of physicians are in DP for income-related reasons (37). In Greece, even with use of constraining mechanisms for DP, physicians tended to receive informal payments (21). In Bangladesh, the expansion of DP was a reaction to the low level of public sector remuneration (18). Generally, in low-income countries, the government often is not able to finance the public sector, and it pays low salaries to physicians. Thus, physicians get a second job (38).

Some studies have shown that DP increases the credibility, sense of value and professional prestige of physicians $(39,40)$. Moreover, the behaviour of specialists is influenced by societal culture and attitudes (41). It was noteworthy that factors such as managerial interference or relationship with patients, which have been reported in high-income countries, were not considered by the participants in the present study (42). Moreover, although career development is a recurring factor in most lowincome countries (42), it was not a factor in the Islamic Republic of Iran. This was most likely because there are more opportunities for professional development for specialists in the public sector.

Our study showed that, given their experience and reputation, senior specialists have more opportunities to work in private practice than their younger peers have, which confirms the findings of other studies $(43,44)$. 
Chawla also suggested that specialists were less likely to attend their primary job in the public sector as they grow older $(44,45)$. Consistent with our study, in Australia, young physicians tended to become less engaged in DP and devoted part of their time to research and education (46). Similar to the Islamic Republic of Iran, in Indonesia and some African countries, new graduate specialists are required to work full time for several years in the public sector (13). Moreover, young doctors with less wellknown backgrounds do not have the capacity to compete with senior physicians and have less chance to engage in DP (47).

With regard to the control mechanisms, in lowincome countries, many health workers tend towards DP because of nonflexible mechanisms in the public sector $(13,48)$. In fact, the contradiction between bureaucracy and the principles of professionalism in the public sector drives the specialists away from the public sector. This is because, in the public sector, they are expected to perform a series of specific tasks at determined hours. Practically, this rigidity has a negative effect on their autonomy and professional creativity (20). In order to increase the effectiveness of control mechanisms, different countries should act in accordance with the particular conditions of the country $(40,49,50)$. In low-income countries such as the Islamic Republic of Iran, with low payments and poor working conditions in the public sector, a complete ban on DP might not be feasible, and any such regulations may be ignored by medical specialists and result in them shifting to the private sector (16). Therefore, governments should seek mechanisms to compensate the difference in income and other conditions between the sectors and reinforce the competitive power of the public sector (13). These mechanisms could include: the financial monitoring of doctors; setting a ceiling for private practice income for public sector physicians; taxbased or insurance-based services; limitation of issuing occupational licenses for private work by specialists; and improving the environment in the public sector by offering nonfinancial incentives such as professional recognition and development opportunities $(20,49)$. The implementation of each of these strategies requires strengthening the role of the Ministry of Health as a steward of the health sector.

Our results confirm other studies with regard to the relationship between available infrastructure and DP. In Uganda, surgeons who require advanced diagnostic and surgical equipment have used surgical centres with better facilities (51). Basu et al. showed that the public sector encounters difficulties with accessibility of facilities, whereas the private sector has better capacity. Thus, doctors have greater accessibility to therapeutic and nontherapeutic facilities in the private sector (52). Kotzee and Couper showed that in South Africa the lack of minimum facilities in the public sector was one of the most important factors for physicians leaving their jobs (53). Also, the private sector, due to its nature of profitability, focuses on marketing to attract more patients and increase its profits, including attracting the most prestigious specialists and providing the best equipment and facilities $(13,52)$. Moreover, our study showed that the regional characteristics of health service locations was one of the factors driving the physicians' tendency towards DP. Similarly, in Africa, the number of private service providers, surgical facilities, regional population and extent of regional development were the most important factors in DP (47). Therefore, in more developed areas where the private sector has better facilities, the chance for specialists to become involved in DP will be greater. Our results suggest that there is similarity between the determinants of DP in the Islamic Republic of Iran and other countries. However, only a small number of studies have examined factors influencing specialists' DP, thus, there is a need for further studies to establish effective mechanisms to manage the factors that influce the tendency towards DP.

The limitations of qualitative studies applied to this study. The main limitation was the small sample size of the qualitative studies. We tried to eliminate this restriction by selecting the most informed and knowledgeable people and analyzing each interview immediately after doing it and enriching each interview with the points raised in the previous interviews. The other limitation was was the possibility of different perceptions of the comments of respondents. In order to compensate for this limitation, we tried to use the member-checking technique. Another disadvantage of this study was that the findings may not be extended to other populations with an equal level of certainty that applies to quantitative studies. For this, we tried to make significant findings through choosing a truly representative sample of the general population from a previously conducted quantitative study.

\section{Conclusion}

Based on the results, management of specialists' DP requires a comprehensive and systemic approach. It seems that, in most countries, total prohibition of DP would be unviable, unfeasible and ineffective. In fact, depending on the capacity and conditions of the countries, different approaches can be adopted. Controlling mechanisms such as reforming the tax and health financing system by setting a ceiling for private sector tariffs and for private practice income of public sector physicians could be envisaged as policy choices. Provision of required infrastructure, such as adequate space and equipment for physicians in public hospitals, or enabling DP in some areas, taking into account regional conditions, including private sector capacity and the economic situation of the people, could be a constructive mechanism to keep specialists in the public sector.

Funding: None.

Competing interests: None declared. 


\section{Facteurs influençant la double pratique des médecins en République islamique d'Iran}

Résumé

Contexte: La double pratique consiste à cumuler plusieurs activités professionnelles différentes, ce qui a des répercussions sur la prestation de services de santé.

Objectif : Identifier les raisons pour lesquelles les médecins ont tendance à exercer en double pratique en République islamique d'Iran.

Méthodes: Nous avons adopté une approche qualitative visant à identifier les facteurs qui influaient sur la double pratique chez les médecins en 2016. Nous avons appliqué une méthodologie d'échantillonnage raisonnée prenant en compte les aberrations; des entretiens approfondis et semi-structurés ont été menés auprès de 14 informateurs clés. L'analyse des données a été effectuée parallèlement au recueil de données, à l'aide d'une analyse de contenu thématique avec le logiciel MAXQDA (version 10.0). Les entretiens ont été poursuivis jusqu'à saturation des données. La qualité de l'étude a été assurée en appliquant les critères proposés par Guba et Lincoln.

Résultats : Les résultats des entretiens ont révélé six thèmes et 16 sous-thèmes au regard de la propension des médecins à exercer la double pratique. Les thèmes principaux comprenaient les incitations financières, les attitudes culturelles à propos de l'identité professionnelle des médecins, l'expérience et le niveau universitaire des médecins, la maitrise des approches dans le secteur public, les infrastructures disponibles pour répondre aux besoins de la population dans le secteur public, ainsi que les caractéristiques régionales concernant l'emplacement des services de santé.

Conclusions : Le recours à la double pratique parmi les médecins est un problème à dimensions multiples, influencé par des facteurs divers tels que les incitations financières, les attitudes culturelles et les infrastructures disponibles. En fonction des capacités et des conditions de chaque pays, le contrôle et la prise en charge de ce phénomène nécessitent l'instauration de mécanismes règlementaires et d'incitations permettant, à long terme, de modifier les différences entre les secteurs privé et public et d'améliorer la motivation des médecins à travailler dans le secteur public.

$$
\begin{aligned}
& \text { أسباب ميل الأطباء المتخصصين نحو الملمارسة المزدوجة في جمهورية إيران الإسلامية } \\
& \text { محبوبة بيات، آزاد شكري، محمود خدادوست، حامد فتاحي، الميرا ميربهاء الدين، ايرج حريرجي، علي أكبري ساري، غلامحسين صالحي زلاني، } \\
& \text { رقية خليل نزاد آراد } \\
& \text { الخلاصة } \\
& \text { الخلفية: المارسة المزدوجة تعني أداء عدة وظائف مختلفة في نفس الوقت ولهذا تأثيرات على خدمات الرعاية الصحية المقدمة. } \\
& \text { الهدف: التعرف على أسباب ميل الأطباء المختصين نحو الممارسة المزدوجة في (بمهورية إيران الإسلامية) ). }
\end{aligned}
$$

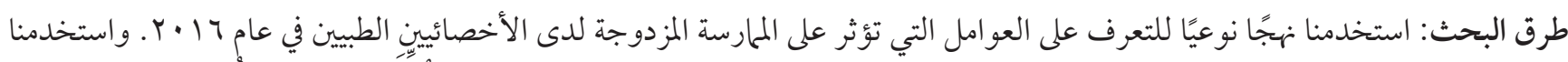

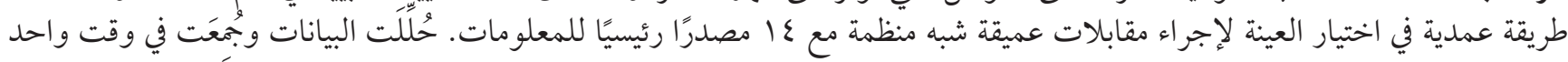

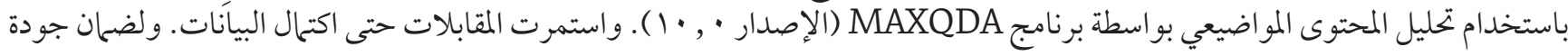

$$
\begin{aligned}
& \text { الدراسة روعيت معايير غوبا ولينكولن المئن }
\end{aligned}
$$

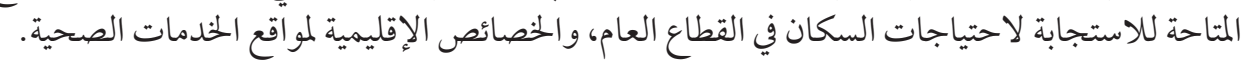

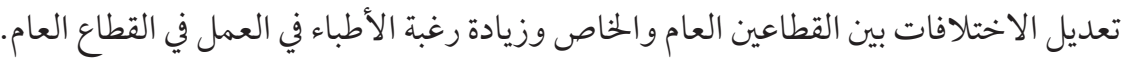

\section{References}

1. World Health Organization. Global strategy on human resources for health: workforce 2030. WHO Library Cataloguing.2016. (http://www.who.int/hrh/resources/pub_globstrathrh-2030/en/).

2. Ashmore J. 'Going private': a qualitative comparison of medical specialists' job satisfaction in the public and private sectors of South Africa. Hum Resour Health. 2013 Jan 3;11(1):1. https://doi.org/10.1186/1478-4491-11-1 PMID:23281664

3. Socha KZ, Bech M. Physician dual practice: a review of literature. Health policy. 2011 Sep 1;102(1):1-7. https://doi.org/10.1016/j. healthpol.2010.10.017 PMID: 21094557

4. González P, Macho-Stadler I. A theoretical approach to dual practice regulations in the health sector. J Health Econ. 2013 Jan;32(1):66-87. https://doi.org/10.1016/j.jhealeco.2012.08.005 PMID:23202256 
5. Eggleston K, Bir A. Physician dual practice. Health Policy. 2006 Oct;78(2-3):157-66. https://doi.org/10.1016/j.healthpol.2005.09.007 PMID:16253383

6. Abdul Rahim R, Mwanri L. Health workforce crisis: recruitment and retention of skilled health workers in the public health sector in Malaysia. Asia Pac J Public Admin. 2012;34(2):157-70. https://doi.org/10.1080/23276665.2012.10779392

7. Humphrey C, Russell J. Motivation and values of hospital consultants in south-east England who work in the national health service and do private practice. Soc Sci Med. (1982). 2004;59(6):1241-50.

8. Bloom G, Standing H, Lloyd R. Markets, information asymmetry and health care: towards new social contracts. Soc Sci Med. 2008 May;66(10):2076-87. https://doi.org/10.1016/j.socscimed.2008.01.034 PMID:18316147

9. Paina L, Bennett S, Ssengooba F, Peters DH. Advancing the application of systems thinking in health: exploring dual practice and its management in Kampala, Uganda. Health Res Policy Syst. 2014 Aug 18;12(1):41. https://doi.org/10.1186/1478-4505-12-41 PMID:25134522

10. Globerman S, Vining A. A policy perspective on "mixed" health care financial systems of business and economics. J Risk Insur. 1998;65(1):57-80. https://doi.org/10.2307/253491

11. Bir A, Eggleston K. Physician dual practice: access enhancement or demand inducement. Tufts University Department of Economics Working Paper. 2003;11.

12. Johannessen K-A, Hagen TP. Physicians' engagement in dual practices and the effects on labor supply in public hospitals: results from a register-based study. BMC Health Serv Res. 2014 Jul 10;14(1):299. https://doi.org/10.1186/1472-6963-14-299 PMID:25011448.

13. Ferrinho P, Van Lerberghe W, Fronteira I, Hipólito F, Biscaia A. Dual practice in the health sector: review of the evidence. Hum Resour Health. 2004 Oct 27;2(1):14. https://doi.org/10.1186/1478-4491-2-14 PMID:15509305

14. García-Prado A, González P. Policy and regulatory responses to dual practice in the health sector. Health Policy. 2007 Dec;84(23):142-52. https://doi.org/10.1016/j.healthpol.2007.03.006 PMID:17449134

15. Chiu Y-C, Smith KC, Morlock L, Wissow L. Gifts, bribes and solicitions: print media and the social construction of informal payments to doctors in Taiwan. Soc Sci Med. 2007 Feb;64(3):521-30. https://doi.org/10.1016/j.socscimed.2006.09.018 PMID:17070971

16. Kiwanuka SN, Kinengyere AA, Rutebemberwa E, Nalwadda C, Ssengooba F, Olico-Okui, et al. Dual practice regulatory mechanisms in the health sector: a systematic review of approaches and implementation. London: EPPI-Centre, Social Science Research Unit, Institute of Education, University of London; 2011.

17. Kiwanuka SN, Kinengyere AA, Nalwadda C, Ssengooba F, Okui O, Pariyo GW. Effects of interventions to manage dual practice. Cochrane Database Syst Rev. 2010(3):CDoo8405. https://doi.org/10.1002/14651858.CDoo8405.

18. Gruen R, Anwar R, Begum T, Killingsworth JR, Normand C. Dual job holding practitioners in Bangladesh: an exploration. Soc Sci Med. 2002 Jan;54(2):267-79. https://doi.org/10.1016/S0277-9536(01)00026-o PMID:11824931

19. Chue P. Incentives to dual practice: new institutional economic analysis of Canada's mixed public-private health sector [thesis]. Tacoma: University of Puget Sound; 2007.

20. Berman P, Cuizon D. Multiple public-private jobholding of health care providers in developing countries. An exploration of theory and evidence. London: Department for International Developmnent Health Systems Resource Centre; 2004.

21. Mossialos E, Allin S, Davaki K. Analysing the Greek health system: a tale of fragmentation and inertia. Health Econ. 2005 Sep;14(Suppl 1):S151-68. https://doi.org/10.1002/hec.1033 PMID:16161195

22. Abera GG, Alemayehu YK, Herrin J. Public-on-private dual practice among physicians in public hospitals of Tigray National Regional State, North Ethiopia: perspectives of physicians, patients and managers. BMC Health Serv Res. 2017 Nov 10;17(1):713. https://doi.org/10.1186/s12913-017-2701-6 PMID:29126453

23. Bayat M. Determinig specialists dual practice level in the country and analysis of affecting factors [thesis]. Tehran: Teheran University of Medical Sciences; 2017.

24. Iranian Employment Law 2010. Tehran: Islamic Parliament of Iran; (http://old.iums.ac.ir/uploads/aeinname_edariestekhdami. pdf, accessed 20 May 2018) (in Farsi).

25. Akbari-sari A. Implementing the full-time practice in Iran health system; perceptions of the medical university chancellors on its challenges, consequences and effective solutions. J Kerman Univ Med Sci. 2013;20(1):40-51 [in Farsi]

26. Moghri J, Rashidian A, Arab M, Akbari Sari A. Implications of dual practice among health workers: a systematic review. Iran J Public Health. 2017 Feb;46(2):153-64. PMID:28451549

27. Babashahy S, Akbarisari A. Assessment and analysis of international experiences in dual practice in public and private settings of healthcare system and regulatory mechanisms. Hakim Res J. 2013;16(2):98-106 (in Persian).

28. Jumpa M, Jan S, Mills A. The role of regulation in influencing income-generating activities among public sector doctors in Peru. Hum Resour Health. 2007 Feb 26;5(1):5. https://doi.org/10.1186/1478-4491-5-5 PMID:17324290

29. Ranjbar H, Haghdoost A-A, Salsali M, Khoshdel A, Soleimani M, Bahrami N. Sampling in qualitative research: a guide for beginning. Ann Mil Health Sci Res. 2012;10(3):238-50.

30. Saunders B, Sim J, Kingstone T, Baker S, Waterfield J, Bartlam B, et al. Saturation in qualitative research: exploring its conceptualization and operationalization. Qual Quant. 2017;52:1893-907. 
31. Corbin J, Strauss A, Strauss AL. Basics of qualitative research, third edition. Thousand Oaks, CA: Sage; 2014.

32. Stake RE. Multiple case study analysis. New York: Guilford Press; 2013.

33. Pope C, Ziebland S, Mays N. Qualitative research in health care. Analysing qualitative data. BMJ. 2000 Jan 8;320(7227):114-6. https://doi.org/10.1136/bmj.320.7227.114 PMID:10625273

34. The law of National Health Insurance in Iran: Islamic Parliament of Iran, 1 (1995).

35. Roulston K. Considering quality in qualitative interviewing. Qual Res. 2010;10(2):199-228. https://doi. org/10.1177/1468794109356739

36. McPake B, Russo G, Tseng F-M. How do dual practitioners divide their time? The cases of three African capital cities. Soc Sci Med. 2014 Dec;122:113-21. https://doi.org/10.1016/j.socscimed.2014.10.040 PMID:25441323

37. Bian Y, Sun Q, Jan S, Yu J, Meng Q. Dual practice by public health providers in Shandong and Sichuan Province, China. London: Health Economics and Financing Programme, London School of Hygiene and Tropical Medicine; 2003.

38. Socha K, Bech M. Dual practitioners are as engaged in their primary job as their senior colleagues. Dan Med J. 2012 Feb;59(2):A4375. PMID:22293048

39. Henderson LN, Tulloch J. Incentives for retaining and motivating health workers in Pacific and Asian countries. Hum Resour Health. 2008 Sep 15;6(1):18. https://doi.org/10.1186/1478-4491-6-18 PMID:18793436

40. Humphrey C, Russell J. Motivation and values of hospital consultants in south-east England who work in the national health service and do private practice. Soc Sci Med. 2004 Sep;59(6):1241-50. https://doi.org/10.1016/j.socscimed.2003.12.019 PMID:15210095

41. Williams ES, Rondeau KV, Francescutti LH. Impact of culture on commitment, satisfaction, and extra-role behaviors among Canadian ER physicians. Leadersh Health Serv. 2007;20(3):147-58. https://doi.org/10.1108/17511870710764005 PMID:20690460

42. El Koussa M, Atun R, Bowser D, Kruk ME. Factors influencing physicians' choice of workplace: systematic review of drivers of attrition and policy interventions to address them. J Glob Health. 2016 Dec;6(2):020403. https://doi.org/10.7189/jogh.06.020403 PMID:27648254

43. Sherr K, Mussa A, Chilundo B, Gimbel S, Pfeiffer J, Hagopian A, et al. Brain drain and health workforce distortions in Mozambique. PloS One. 2012;7(4):e35840. https://doi.org/10.1371/journal.pone.0035840 PMID:22558237

44. González P, Macho-Stadler I. A theoretical approach to dual practice regulations in the health sector. J Health Econ. 2013 Jan;32(1):66-87. https://doi.org/10.1016/j.jhealeco.2012.08.005 PMID:23202256

45. Chawla M. Public-private interactions in the health sector in developing countries: sharing of labor resources. [thesis], Boston University, 1996.

46. Cheng TC, Joyce CM, Scott A. An empirical analysis of public and private medical practice in Australia. Health Policy. 2013 Jun;111(1):43-51. https://doi.org/10.1016/j.healthpol.2013.03.011 PMID:23602546

47. Russo G, McPake B, Fronteira I, Ferrinho P. Negotiating markets for health: an exploration of physicians' engagement in dual practice in three African capital cities. Health Policy Plan. 2014 Sep;29(6):774-83. https://doi.org/10.1093/heapol/czto71 PMID:24077880

48. Anderson I, Meliala A, Marzoeki P, Pambudi E. The production, distribution, and performance of physicians, nurses, and midwives in Indonesia: an update. Washington (DC) World Bank; 2014 (http://documents.worldbank.org/curated/ en/912471468254690409/pdf/913240WPoUHCoCooBox385331BooPUBLICo.pdf, accessed 13 June 2018).

49. González P. Should physicians' dual practice be limited? An incentive approach. Health Econ. 2004 Jun;13(6):505-24. https://doi. org/10.1002/hec.89o PMID:15185383

50. Rickman N, McGuire A. Regulating providers' reimbursement in a mixed market for health care. Scott J Polit Econ. 1999;46(1):5371. https://doi.org/10.1111/1467-9485.00120

51. Paina Bergman L. Dual practice in Kampala, Uganda: a mixed methods study of management and policy [thesis]. Baltimore: Johns Hopkins University; 2014.

52. Basu S, Andrews J, Kishore S, Panjabi R, Stuckler D. Comparative performance of private and public healthcare systems in lowand middle-income countries: a systematic review. PloS Med. 2012;9(6):e1001244. https://doi.org/10.1371/journal.pmed.1001244 PMID:22723748

53. Kotzee TJ, Couper ID. What interventions do South African qualified doctors think will retain them in rural hospitals of the Limpopo province of South Africa? Rural Remote Health. 2006 Jul-Sep;6(3):581. PMID:16965219 